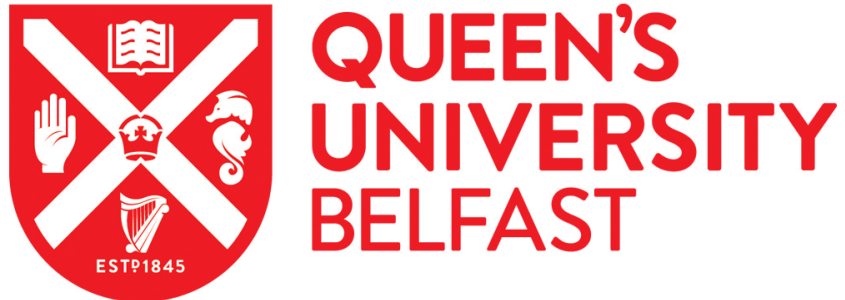

\section{The impact of hydrogeology on the instability of a road cutting through a drumlin in the North of Ireland}

Hughes, D. A. B., Clarke, G. R. T., Harley, R. M. G., \& Barbour, S. L. (2016). The impact of hydrogeology on the instability of a road cutting through a drumlin in the North of Ireland. Quarterly Journal of Engineering Geology \& Hydrogeology. https://doi.org/10.1144/qjegh2014-101

Published in:

Quarterly Journal of Engineering Geology \& Hydrogeology

Document Version:

Peer reviewed version

Queen's University Belfast - Research Portal:

Link to publication record in Queen's University Belfast Research Portal

Publisher rights

(c) The Authors, published by Geological Society of London [2016]

Quarterly Journal of Engineering Geology \& Hydrogeology [Volume/2016 http://qjegh.lyellcollection.org/content/early/2016/02/05/qjegh2014101

\section{General rights}

Copyright for the publications made accessible via the Queen's University Belfast Research Portal is retained by the author(s) and / or other copyright owners and it is a condition of accessing these publications that users recognise and abide by the legal requirements associated with these rights.

Take down policy

The Research Portal is Queen's institutional repository that provides access to Queen's research output. Every effort has been made to ensure that content in the Research Portal does not infringe any person's rights, or applicable UK laws. If you discover content in the Research Portal that you believe breaches copyright or violates any law, please contact openaccess@qub.ac.uk. 
- For submission to the Quarterly Journal of Engineering Geology and Hydrogeology

- Text written 2014. Revised 2015.

- Main text and tables: 5683 words (excluding references); Number of figures: 15 ; Number of tables: 2 .

Title: The impact of hydrogeology on the instability of a road cutting through a drumlin in the North of Ireland

Author 1

- Dr. D.A.B. Hughes, BSc PhD MIEI MICE FCIHT CEng

- School of Planning, Architecture and Civil Engineering, Queen's University Belfast, UK.

d.hughes@qub.ac.uk

\section{Author 2}

- Dr. G.R.T. Clarke, MEng PhD

- Sweco Norge AS, Drammensveien 260, Box 80, 0212 Oslo, Norge

gordon.clarke@sweco.no

\section{Author 3}

- Ms. R.M.G. Harley, MEng

- School of Planning, Architecture and Civil Engineering, Queen's University Belfast, UK.

r.harley@qub.ac.uk

\section{Author 4}

- Prof. S.L. Barbour, BE MSc PhD

- Department of Civil and Geological Engineering, University of Saskatchewan, Canada.

lee.barbour@usask.ca

Full contact details of corresponding author:

Ruth Harley

Research Fellow

School of Planning, Architecture and Civil Engineering

Queen's University Belfast

Belfast

United Kingdom

BT7 5AG

Tel.:02890975633 Mob. :(+44) 07731443326 Email: r.harley@qub.ac.uk 


\section{Abstract}

49 This paper describes the hydrogeological processes which caused unexpected instability and 50 quick conditions during the excavation of a $25 \mathrm{~m}$ deep cutting through a drumlin in County Down, 51 Northern Ireland. A conceptual hydrogeological model of the cutting, based on pore pressures 52 monitored during and after the excavation demonstrates how quick conditions at the toe of the 53 cutting caused liquefaction of the till. Stability of the cutting was re-established by draining the 54 highly permeable, weathered Greywacke which underlies the drumlin, through the use of a deep 55 toe drain. In spite of this drainage, the cutting was only marginally stable due to the presence of 56 a low permeability zone in the till above the bedrock which limits the reduction of elevated pore 57 pressures within the upper to mid-depths of the drumlin. The factor of safety has been further 58 improved by the addition of vertical relief drains at the crest and berm of the cutting to relieve 59 the pore-pressures within the upper till by intercepting the weathered bedrock. The paper also 60 highlights the importance of carrying out an adequate site investigation compliant with Eurocode $61 \quad 7$ and additional monitoring in excavations in stiff, low permeability till.

\section{Keywords}

64 Geotechnical Engineering; Roads and Highways; Site Investigation.

65

66

67 
69 There are few documented case studies which have explored the nature of the hydrogeology of 70 drumlin swarms in Northern Ireland, fewer still that have directly illustrated the importance of these hydrogeological systems to the geotechnical performance of the civil infrastructure, such as road and rail cuttings. This unique case history highlights the critical importance for geotechnical engineers to fully understand the hydrogeology within drumlins and the impact it may have on the geotechnical performance. This case study describes the conditions encountered in a large $(25 \mathrm{~m}$ high) excavation, through a drumlin formed in lodgement till near Loughbrickland, Northern Ireland in 2004. It tracks the hydrogeological behaviour from the start of excavation, through the onset of flowing artesian conditions (which led to quick conditions at the toe of the slope), to the subsequent stabilisation of the excavation using drainage.

There have been few opportunities to examine in detail the stability of large cuttings in till slopes in Ireland, as most alignment designs have avoided the creation of large cut or fill slopes. However, recent efforts to improve road alignments on existing carriageways have required larger earthworks. The stability of these large cuttings in Northern Ireland have generally been assessed by characterisation of the geotechnical and geological properties within a series of borings aligned with the proposed carriageway and applying generalised slope stability criteria without detailed consideration of the site specific hydrogeology. The Loughbrickland cutting was designed using this standard approach; however, in this case, what appeared to be a simple excavation, through an essentially stiff and 'dry' till was almost compromised, and certainly made more difficult, by a flow regime generated during construction which led to the development of 'quick' conditions and a toe failure.

90

The objectives of this paper are to characterise the hydrogeology of a large drumlin in Northern Ireland, and to illustrate how the hydrogeological conditions, combined with the construction sequence, led to elevated pore-pressures and upward gradients within the toe of the cutting, which eventually led to quick conditions at the base of the excavation and instability of the slope. The paper also states the required remedial measures which were implemented to provide sufficient stability.

\subsection{Hydrogeology of drumlins}

Little previous work has been carried out on characterising the groundwater flow through drumlins in Ireland using field data. Fitzsimons and Misstear (2006) highlight the importance of developing a conceptual understanding of the influence of geology on recharge mechanisms and recharge rates in tills. Using a soil moisture budget with a one-dimensional numerical model, Fitzsimons and Misstear (2006) verified that the most important factor controlling the recharge coefficient is the hydraulic conductivity of the till. These investigations are however 
104 hypothetical scenarios of till properties and hydraulic gradients with little field data available.

105 Fissuring in till has also been recognised as having a fundamental influence on soil properties 106 such as the hydraulic conductivity which will then affect the hydrogeology of drumlins. McGown 107 has published a number of papers (McGown \& Radwan, 1974; McGown et al., 1974; McGown 108 \& Radwan, 1975) which show that fissuring present in Scottish deformation tills led to 109 preferential flow of water through the fissures. Hanranhan (1977) has also observed fissures in 110 Irish till, and an investigation into the failure of a till cutting in Northern Ireland revealed a layer 111 of heavily fissured, stone-free, brown clay coincident with the basal slip plane (Hughes et al., 112 2007). Fissures were observed in the till at the Loughbrickland site at the toe of the excavation 113 and could be attributed to some combination of shear deformation during formation of the till, 114 stress relief during the excavation and high hydraulic gradients through the till at the base of 115 excavation.

\subsection{Background}

117 In 2004, Roads Service, now TransportNI (TNI) (One of two core groups within the Department 118 for Regional Development (DRD), Northern Ireland) commenced a construction project to 119 upgrade a section of road to dual carriageway on the A1, the main Belfast to Dublin road (Euro

120 Route 1) near Loughbrickland (Figure 1). The improvement in horizontal road alignment 121 necessitated the excavation of this major cutting through a drumlin. The road cutting at 122 Loughbrickland has many similarities to the cutting that failed at Dromore (Hughes et al., 2007). 123 They are both located in the same geological setting and drumlin field. Loughbrickland is only $12417 \mathrm{~km}$ South-West of Dromore (Figure 1) and the road cutting is similar in geometry and 125 excavated depth.

TNI recognised that the Loughbrickland cutting provided an excellent research opportunity to better understand the effect of climate on the mechanisms that govern the long-term strength and stability of tills as well as the importance of understanding the influence of drumlin composition, till structure and hydrogeology on slope stability. As a result, TNI initiated a research partnership with Queen's University Belfast (QUB) to study the hydrogeology and long-term stability of cuttings in till. TNI facilitated this project by providing funding for a ground investigation, geotechnical instrumentation and practical assistance. The research project commenced after the geotechnical design had been completed, and therefore the research findings were not available to inform the geotechnical design of the cutting or the construction sequence. The characterisation of the hydrogeological system subsequently developed by QUB was able to inform the remedial works undertaken during construction (as discussed later in the article). The site has since provided an 11 year continuous dataset of pore water pressures in the cutting, from the beginning of construction to present, which is giving a unique 
understanding of how the internal pore water pressures in the till are affected by seasonal weather cycles.

\section{$141 \quad 2.1$ Site description, ground investigation and instrumentation}

142 The cutting is situated on a drumlin known as The Three Sisters (Figure 1), approximately 125 143 metres above mean sea level (drumlin hollow approximately $80 \mathrm{mAOD}$ ). The $\mathrm{A} 1$ in this region 144 passes through agricultural land, which is typically described as glacial terrain comprised of 145 drumlin swarms. The location of the Loughbrickland cutting, County Down, was subjected to at 146 least two glacial advances during the Midlandian stage, from 75,000 to 10,000 years ago 147 (Doran, 1992). It was the last major re-advance of ice, around 25,000 years ago (Late 148 Midlandian), when ice moved generally northwards and southwards from a Lough Neagh ice 149 axis depositing and moulding the till into the numerous drumlins that dominate the topography 150 of the area (McCabe et al.,1999). It is generally accepted that the drumlins of Northern Ireland 151 were formed by deposition beneath fast flowing ice (Dardis and McCabe, 1984), resulting in a 152 thick layer of upper lodgement till overlying a core of lower (older) lodgement till (Hill, 1968). The 153 location of the Loughbrickland site is shown on a geology bedrock map in Figure 2.

154 The preliminary site investigation (SI) was completed by TNI prior to the initial road design 155 (Construction Service, DFP, 2000). Fieldwork for this investigation was carried out between 156 August 1999 and February 2000. The preliminary TNI site investigation covered the entire $11 \mathrm{~km}$ 157 stretch of new dual carriageway, but the boreholes at the Loughbrickland cutting did not extend 158 to the full depth of the cutting as the vertical alignment of the road was lowered prior to 159 construction. A limited subsequent ground investigation to install monitoring equipment at the 160 location of the cutting was undertaken in January - February 2004, just prior to commencement 161 of construction and excavation on site in the spring of 2004 (Clarke 2006; Clarke, 2007). Figure 1623 shows the borehole locations within the road cutting.

163 TNI's initial site investigation included: five trial pits (opened using a light mechanical excavator) 164 to a maximum depth of $3 \mathrm{~m}$ and 9 boreholes drilled (percussively) to a maximum depth of $19 \mathrm{~m}$. 165 This investigation confirmed the Geological Survey Northern Ireland descriptions (GSNI, 2004) 166 that the drumlin was predominately cohesive lodgement till. The material was described as 167 slightly sandy, clayey silt with cobbles and boulders. Two of the boreholes located within the 168 main section of the road cutting showed an extensive depth of till (12-19m). Unfortunately, these 169 boreholes were not continued to bedrock and no measurements of pore pressure were made. 170 Granular soils were identified in a few boreholes (well graded sands and gravels), in trial pits 171 (silty sand layers), and in the rock truthing boreholes along the toe of the cutting (Figure 3b). 172 The underlying bedrock was encountered in further boreholes and trial pits, showing it to consist 173 of completely to moderately weathered Greywacke with completely weathered slaty mudstone 174 interbeds, typical of the Gala Group bedrock geology of the area (Anderson, 2004). The 
bedrock surface reflects to some extent the drumlin topography as evident in seismic refraction surveys (seismic velocity tomography) used to map the bedrock surface. The compression (P) wave velocities of the bedrock surface were approximately $4000 \mathrm{~m} / \mathrm{s}$ with the P-wave velocities within the overlying tills ranging from $300-3000 \mathrm{~m} / \mathrm{s}$, generally increasing with depth (Kulpa, 2013). The surveys concluded that the surface of the bedrock is often highly fractured and therefore has a high hydraulic conductivity although it may not be continuously hydraulically connected.

The Loughbrickland cutting is $25 \mathrm{~m}$ high, with a slope angle of approximately $26^{\circ}$. The site has a number of layers, including agricultural soil (0-1mBGL), underlain by an upper till layer (1$10 \mathrm{mBGL}$ ) and a lower till layer (10-24mBGL). Beneath the till, a layer of dense sandy gravelly material (bedrock contact zone) overlies the weathered greywacke (0.5-1.3m thickness) as illustrated in Figure 3(c). The till layers have a maximum depth of $24 \mathrm{~m}$ at the centroid of the drumlin, with decreasing depth with distance. It is a dense material consisting of particles ranging in size from fine clays to mass boulders.

The geotechnical properties of the tills were measured in a subsequent SI carried out by QUB in January - February 2004 and the natural water content, along with the Atterberg liquid and plastic limits are presented in Table 1. The water contents were calculated for the matrix after discarding the stony material retained on the $5 \mathrm{~mm}$ sieve. The water content with the gravel or large particles sizes included are also presented for comparison to highlight that the matrix (stone-free) water contents are generally 30-50\% higher than the intact sample water contents. This correction was carried out as the authors believed that the till behaviour was dominated by the clay matrix and, given the variability of the stone content in the tills, the matrix water content was more indicative of the soil behaviour. A summary of the Particle Size Distribution (PSD) ranges for the Loughbrickland site is also presented in Table 1, alongside typical PSD ranges for another cutting site along the $\mathrm{A} 1$ at Dromore (Figure 1) as well as typical ranges for Dublin Boulder Clays. It can be seen that the material is variable in nature, but with clay contents between 16 and $26 \%$. During excavation of the cutting, large inclusions of soils with a higher clay content were also observed (Figure 4). These inclusions reinforce the appreciation of the highly heterogeneous nature of drumlin formations. Zones of highly plastic clays within the drumlins could potentially coincide with rupture surfaces, leading to the development of zones of softening within cut slopes, as was observed by Hughes et al. (2007) at the failure of the Dromore cutting.

207 A range of soil strength parameters as determined from laboratory and field testing (Clarke, 208 2007; McLernon, 2014; Carse, 2014), with the selected characteristic values used in the slope 209 stability analysis are presented in Table 2. The natural matrix water content of the tills is 210 marginally lower than the plastic limits highlighting the stiff nature of this material. The Atterberg 
211 limits are plotted on the ' $A$ ' line chart and the values lie along the ' $T$ ' line as predicted by Trenter 212 (1999).

\section{$213 \quad 2.2$ Estimation of in situ hydraulic conductivity}

214 The hydraulic conductivity of the till was measured using in situ methods such as falling or rising 215 head tests within screened standpipes, or through the use of infiltrometer tests, such as the 216 Guelph permeameter in the near surface zone; the results from these tests are reported in

217 Figure 5. The upper most metre of the drumlin comprises the A and B soil horizons, with its 218 genesis in the upper till. The hydraulic conductivity of this near surface soil is in the range of $2191 \times 10^{-7}$ to $1 \times 10^{-5} \mathrm{~m} / \mathrm{s}$. Below this near surface layer lies an upper till, in which the hydraulic 220 conductivity is still greater than one would expect based on texture alone, with hydraulic 221 conductivity values ranging from $1 \times 10^{-9}$ to $4 \times 10^{-8} \mathrm{~m} / \mathrm{s}$. The water table within the drumlin lies 222 within this upper till layer at depths ranging from near surface to nearly $12 \mathrm{~m}$ below ground, 223 fluctuating seasonally. The hydraulic conductivity of the lower till ranges from $1 \times 10^{-10}$ to $3 \times 10^{-}$ $224{ }^{9} \mathrm{~m} / \mathrm{s}$. The general decrease in hydraulic conductivity with depth is likely to be the result of 225 decreasing fracturing with depth associated with weathering (e.g. historical wet/ dry cycles) or 226 as a result of depositional processes (e.g. shearing). Similar observations have been reported 227 by van der Kamp \& Hayashi (2009). The division of the till profile into an upper and lower till is 228 based on both the measured hydraulic conductivity values and the observed hydraulic gradients 229 (see Section 4.1 for more detail on the division of the till profile).

230 The bedrock underlying the till is comprised of an upper, highly permeable zone of weathered 231 and fractured bedrock, overlying more intact bedrock. The hydraulic conductivity of the 232 weathered bedrock zone is estimated to be in the order $1.0 \times 10^{-6} \mathrm{~m} / \mathrm{s}$ as measured by Kulpa 233 (2013).

\subsection{Instrumentation}

235 Figure 3(a) shows the layout of the initial piezometers at the site. A series of nested 236 piezometers were installed at the crest of the cutting, $20 \mathrm{~m}$ behind the crest and beneath the toe 237 of the cutting prior to excavation. Three piezometers were installed in each borehole at one third 238 and two thirds the overall depth of the till layer, and also in the fractured surface of the bedrock 239 (Fig. 3c). The vibrating wire piezometers were all placed in $50 \mathrm{~mm}$ standpipes with a $1 \mathrm{~m}$ slotted 240 screen tip backfilled with gravel. The boreholes were backfilled with bentonite between each 241 standpipe tip to ensure there was no direct hydraulic connection between each piezometer. In 242 order to improve the response time of the piezometers, pneumatic packers were used to limit 243 the intake volume (Clarke, 2007).

\subsection{Construction Chronology and Observations}


245 The Loughbrickland excavation was undertaken as a series of stepped benches using a truck

246 and shovel type of excavation. The location of the standpipes in boreholes 3 and 4 were

247 exposed during the excavation, therefore the standpipes were periodically cut to the level of the

248 excavation and protective manhole covers replaced over the standpipes as the excavation

249 proceeded. It is important to note that there were no significant 'step' changes in the monitored

250 heads within the standpipes located in the bedrock contact zone (BH1-1, BH2-1 and $\mathrm{BH} 4-1)$.

251 Subsequent flowing artesian conditions developed at the toe of the cutting as the elevation of 252 the overlying clay till dropped below the head level within these standpipes (Figure 6).

253 Ultimately, these conditions became critical with the uplift pressure exceeding the overburden

254 pressure with subsequent quick conditions of the till and the initiation of a toe failure.

255 The excavation chronology and head conditions within the bedrock zone at the toe of the slope

256 are summarised in Figure 6. This Figure shows the head levels within all the standpipes in the

257 bedrock contact zone (BH1-1, BH2-1 and BH4-1) and the excavated level at $\mathrm{BH} 4$. In general,

258 there were four distinct stages to the excavation as summarised below.

259 3.1 Stage 1 Natural drumlin hydrogeological flow system ( $9^{\text {th }}$ March $-2^{\text {nd }}$ April 2004)

260 The initial head levels within the 3 standpipes in the bedrock contact zone correlated closely 261 highlighting the relatively low gradients within the bedrock aquifer due to the presence of a till 262 confining layer down-gradient of the toe. The similar head levels within the bedrock aquifer 263 suggest that the weathered bedrock was highly permeable and hydraulically connected.

264 3.2 Stage 2 Excavation with minor drop in hydraulic head $\left(\mathbf{2 2}^{\text {nd }}\right.$ April $-\mathbf{2 3}^{\text {rd }}$ July 2004)

265 The major excavation period commenced on $22^{\text {nd }}$ April 2004, and during the next three months 266 the bedrock acted as a confined aquifer with head levels in the bedrock contact zone reducing 267 gradually by approximately $1 \mathrm{~m}$.

$268 \quad 3.3$ Stage 3 Development of flowing artesian conditions and initial dissipation of heads due to 269 flow to excavation (23 ${ }^{\text {rd }}$ July $-\mathbf{1}^{\text {st }}$ September 2004)

270 On $23^{\text {rd }}$ July, the level of the excavation dropped below the elevation of the head in the 271 standpipes (BH1-1, BH2-1 and BH4-1, Figure 6) resulting in the development of flowing artesian 272 conditions within the bedrock aquifer over the toe of the cutting. Standpipe BH4-1 was not 273 sealed and this resulted in a continual discharge of water from the standpipe of approximately $2740.1 \mathrm{l} / \mathrm{s}$. Although the flow out of BH4-1 was relatively small and not expected to cause significant 275 drawdown in the aquifer, there was a clear rapid drop in head in $\mathrm{BH} 1-1$ and $\mathrm{BH} 2-1$ due to 276 discharge into the excavation. 
277 3.4 Stage 4 Initiation of critical conditions and increased rate of head drop with time ( $1^{\text {st }}$ 278 September $-11^{\text {th }}$ November 2004)

279 Standpipe BH4-1 was cut off following excavation of this standpipe location on September $1^{\text {st }}$. 280 (BH1-1 and $\mathrm{BH} 2-1$ still allowed monitoring of bedrock contact zone head levels). Seepage from 281 the excavation face and base continued during this time. It was anticipated that further 282 excavation would result in loss of toe stability; however, a decision was made to manage water 283 and excavation conditions using conventional sumping and excavation methods. The 284 excavation of an additional $4 \mathrm{~m}$ of overburden resulted in the development of critical conditions 285 in which the overburden stress was less than the uplift pore water pressure. This ultimately 286 resulted in a failure of a section of the cutting toe with three shallow slip failures (Figure 7) due 287 to the unexpected development of flowing artesian (quick) conditions, a condition which is more 288 commonly associated with non-cohesive soils. Figure $3(b)$ and 6 illustrates the location of the 289 potentiometric surface of the aquifer compared to the excavated ground surface. Figure 8 290 illustrates the repair of the surface failures at the toe of the cutting as a result of the developed 291 artesian conditions.

292 In order to stabilise the toe a series of boreholes were drilled into the bedrock contact zone 293 along the toe of the slope to allow a relief of the excess pore pressure within the bedrock aquifer 294 (November, 2004 - Figure 3). Figure 3 shows the 20 rock boreholes (RT) that were drilled to the 295 bedrock surface. These holes highlight the presence of layers of till, gravelly sand and 296 weathered greywacke rock. The boreholes were completed from North-South (RT1-20) and 297 were cored to the bedrock through the bedrock contact zone. It was interesting to note that 298 there was no water strike in boreholes RT1-5, despite RT5 being located within the bounds of 299 the toe failure. In addition the material underlying the till (RT1-5) consisted of $0.5-3.5 \mathrm{~m}$ of dry 300 gravelly sand. Based on the drilling program and a comparison of the heads within the bedrock 301 aquifer relative to the ground surface it was determined that the primary source of the flowing 302 artesian conditions was between RT6-13. Borehole 6 was the first borehole where a water strike 303 occurred and flowing artesian conditions were observed (Figure $3 b$ ). Water flow was observed 304 immediately when the bedrock contact zone was reached during drilling. Flowing artesian 305 conditions continued to be observed in RT6-13, whilst RT14-16 remained flooded and RT17-21 306 and RT1-5 were dry. A standpipe placed in RT10 (close to original BH3) at the bedrock contact 307 was used to observe head conditions. As shown in the photograph in Figure 7 (b) the elevation 308 of these heads were above the excavated ground elevation of $107.5 \mathrm{~m}$ (Figure 6) clearly 309 demonstrating the flowing artesian conditions.

310 The bedrock contact zone is integral to the hydrogeological regime in the drumlin. The bedrock 311 contact zone has been identified throughout the site in various boreholes. The layer was 312 identified as a highly permeable zone $\left(>1 \times 10^{-5} \mathrm{~m} / \mathrm{s}\right)$ which can serve as an under drain to the till 313 if it is free to drain. The pre-excavation head levels (approximately $107.1 \mathrm{~m}$ ) within this unit as 
314 measured in the lower standpipes in $\mathrm{BH} 1, \mathrm{BH} 2 \& \mathrm{BH} 3$ were very similar and were observed to 315 respond simultaneously. The presence of this confined aquifer was also identified in many of 316 the subsequent rock truthing boreholes along the toe of the cutting, and was potentially part of 317 the same continuous zone (Figure $3 b$ ). No further boreholes were cored to assess the spatial 318 extent of the aquifer contained within the bedrock contact zone in the east-west direction. TNI 319 cored a borehole (BH7 - see Figure 9) which was located approximately $20 \mathrm{~m}$ east of BH3 320 (closer to Lough Brickland). The borehole ended within the till at a depth of 19.0m (92.3mAOD).

In order to provide post-construction control of heads within this unit, it was decided to construct a deep toe drain. Construction of the toe drain resulted in the complete dissipation of the heads within this aquifer in all four boreholes (Figure 6) and ultimately resulted in the lower weathered bedrock returning to a confined or possibly even an unconfined aquifer. the equilibrium pore water pressures and head levels within each standpipe (11 th April 2005). It is important to note that the head levels within the upper zone are similar to those preexcavation; however, draining of the bedrock contact zone reduced the pore water pressures at the bedrock surface and across the lower till.

\subsection{Analysis}

331 The relationship between the evolving hydrogeological system during excavation and the resulting impact this had on geotechnical stability is more clearly illustrated in this section through the development of a conceptual and numerical model of the hydrogeology and slope stability of the section. The existing site characterisation information along with monitoring data are used to first construct a conceptual and numerical model of the pre-construction conditions.

336 For the purposes of this paper, the flow system is conceptualised as a topographically driven groundwater flow system in which recharge occurs across the upland of the drumlin, with subsequent discharge to the lower slope and wetlands at the toe of the drumlin. The system is simulated as a steady-state flow system based on estimates of average annual recharge.

340 Ongoing work, exploring the dynamic nature of the seasonal recharge highlights that there is 341 little recharge to the till during the summer growing season when the soil zone develops a soil 342 moisture deficit (SMD). Once this SMD is overcome by rainfall exceeding evapotranspiration, 343 water is released into the till during the autumn and winter, resulting in a rapid rise of the water 344 table within the upper till. When the SMD condition is re-established in the spring, the water 345 table slowly falls as water is drained from the upper till by lateral flow due to the slope of the 346 drumlin and vertically through the lower till and into the underlying weathered bedrock aquifer.

347 A surface flux (q) is applied across the drumlin to represent the average annual recharge to the 348 drumlin. The value of this flux is estimated by simulating the flow through the drumlin using 
estimated hydraulic conductivity values and matching the observed values of the average

350 annual heads. Following this initial characterisation of the system, the recharge rate and 351 properties are held constant and the evolution of the system is illustrated as a series of

352 'equilibrium' flow systems developed as a result of the presence of the excavation.

\section{$353 \quad 4.1$ Generalised flow system prior to excavation}

354 The flow domain was conceptualised as two layers of till (upper and lower till) overlying the 355 weathered bedrock zone. The presence of an upper and lower till zone is supported by more 356 recent seismic refraction surveys which show a clear increase in shear wave velocities (Vs) 357 from approximately 400 to $700 \mathrm{~m} / \mathrm{s}$ corresponding to an increase in stiffness. There is a slight 358 change in colour from grey to dark grey. The watershed divide running along the centre of the 359 drumlin was taken to also represent a groundwater divide, and is consequently a lateral zero 360 flux boundary. Recent investigations including seismic surveys have provided further support for 361 this assumption (Kulpa, 2013). The base of the weathered bedrock zone serves as a lower 362 impermeable boundary condition. Lough Brickland provides a constant head boundary 363 (83mAOD) for the flow domain and the lower slope position is identified in the model as a 364 potential seepage zone which allows groundwater to discharge to the ground surface if the head 365 exceeds those of the ground surface. The model was constructed within a commercial finite 366 element seepage analyses package called SEEP/W (GeoStudio, 2010).

367 Figure 11 shows the simulated flow system based on the pre-construction geometry for an 368 annual recharge rate of $35 \mathrm{~mm}$ (Clarke, 2007). The modelled results were in strong agreement 369 with the equilibrated field observations prior to construction (22 ${ }^{\text {nd }}$ April 2004) as shown in Figure 370 12. This agreement is not unique and would be attainable with any assigned recharge rate as 371 long as the proportionality between the recharge rate and the hydraulic conductivity of the till 372 units was maintained. However; given that the hydraulic conductivity used for the two till units is 373 consistent with the hydraulic conductivity measured in situ the results seem reasonable. Recent 374 work at the site (McLernon, 2014) has been undertaken to define the seasonal variations in 375 recharge based on detailed field monitoring of the active surface zone and soil water balance 376 modelling. McLernon's (2014) work suggests that the annual average recharge rates may be 377 higher ( in the range of 40 to $70 \mathrm{~mm} /$ year).

378 The drumlin hydrogeologic regime (Figure 11b) is a typical example of a topographically driven 379 flow system (Freeze and Cherry, 1979). A hinge point has been drawn in Figure 11(b) 380 representing the transition between recharge and discharge into the drumlin. The subtle 381 variation in hydraulic conductivity between upper and lower till zones has a strong influence on 382 the location of the seepage face in the drumlin and the distribution of head within the upper till. 383 There is a distinct contrast in the seepage regimes for the upper and lower till zones. The 384 seepage in the upper till zone is predominately lateral in contrast to the vertical downward 

described in Freeze and Cherry (1979). In the lower slope, groundwater flow is vertically upwards resulting in surface seepage from the slope. Field observations and anecdotal evidence from the local farmer has confirmed that the lower slope is soft and wet throughout the year in contrast to the upper slope.

390 The stability of the drumlin slope prior to excavation was analysed using the pore-pressure regime represented by the simulated flow system and the laboratory measured strength parameters outlined in Table 2. Analyses were undertaken using the limit equilibrium,

393 Morgenstern-Price method with the use of the commercial software package, SLOPE/W 394 (GeoStudio, 2010).

\subsection{Analyses of Excavation to Failure Sequence}

396 The simulated steady-state flow system during excavation shown in Figure 13 highlights that 397 there were relatively minor decreases in head within the underlying weathered bedrock and the 398 till during the excavation prior to the onset of flowing artesian conditions and critical uplift. 399 Critical uplift conditions developed during the final stages of excavation, with the total head in 400 the confined aquifer exceeding the elevation at the base of the cut. Advancing the excavation to $40198 \mathrm{mAOD}$, the lowest point of the cutting caused three shallow slip failures and a failure in the 402 cutting toe.

403 The minimum FoS calculated for the natural slope prior to excavation using the drumlin 404 seepage analysis was 2.3. This high FoS highlights that the drumlin was in a stable condition in 405 spite of the elevated water pressures and saturated conditions at the toe of the slope prior to 406 excavation. An analysis of the stability of the slope for the conditions that existed immediately 407 after excavation is shown in Figure 14. This analysis points to the potential formation of an 408 approximately circular toe failure with an optimised factor of safety (FoS) marginally greater than 409 unity $(F \circ S=1.0)$. It should be noted however that this extended failure surface was never 410 actually generated in situ as the quick (flowing artesian) conditions led to sloughing at the toe of 411 the cutting (Section 3.4).

412 The value of constructing a toe drain into the bedrock surface to dissipate any excess pressures 413 within the bedrock aquifer can be assessed by assigning a drainage boundary condition (i.e. $414 \mathrm{~h}=\mathrm{z}$ ) to the location of the drain. The groundwater flow and stability analyses for this condition 415 are illustrated in Figure 15. It is interesting to note that the presence of the toe drain does result 416 in a marginal improvement in stability of the slope (FoS =1.1), however, a FoS of 1.1 is not 417 considered an adequate long-term factor of safety for design, and therefore additional drainage 418 was required to further strengthen the slope. The reason for this initial marginal increase is 419 apparent if the flow system before and after construction of the toe drain is compared. Although 420 the heads within the lower aquifer are reduced, the drain has little impact on the heads within 
the upper till layer. This unconfined flow system is still causing elevated pore-pressures near the

422 base of the slope at the interface between the two till units. A further increase in the FoS of this

423 slope requires either flattening of the slope above this location or further drainage to relieve the

424 pore-pressures within the upper till. This latter option was trialled by TNI in 2015 with the

425 construction of vertical relief drains from ground surface at the crest and berm of the cutting

426 through the till, vertically into the underlying fractured bedrock. This vertical drainage has

427 resulted in a localised further increase of the FoS to 1.4.

\subsection{Conclusion}

429 During the excavation at the Loughbrickland site, the unique hydrogeological conditions 430 combined with the construction sequence, led to elevated pore-pressures and upward gradients 431 within the toe of the cutting. This eventually led to artesian (quick) conditions at the base of the 432 excavation and instability of the slope. A toe drain was added to dissipate excess pressures; 433 however this only marginally improved the FoS. Vertical relief drains were subsequently 434 installed at the site to aid the drainage of the upper till layer, using the drainage of the fractured 435 bedrock layer to drain below the site, which has further increased the FoS.

436 The consequences of a limited preliminary site investigation prior to site development led to a 437 situation where the toe of the slope failed, which will have softened the till in a zone which is 438 susceptible to progressive failure (Harley et al., 2014). Climate variability has brought more 439 extreme weather conditions, which has proven to trigger slope failures across the UK, especially 440 during the extreme events of 2012 where rainfall records showed it to be the second wettest 441 year in the UK since national records began in 1910. The pore pressures at the Loughbrickland 442 site have been continuously monitored since excavation in 2004, providing a unique long-term 443 dataset to better understand the hydrogeological conditions of a till cutting and to further 444 investigate the effect of pore pressure dynamics on tills in Northern Ireland.

445 This case study reinforces the necessity of carrying out a full ground investigation in compliance 446 with Eurocode 7, with the associated development of a Conceptual Site Model characterising 447 the soil properties and hydrogeology. This should be completed before any ground works 448 commence in order to inform the geotechnical design and reduce geotechnical risk, even where 449 works involve an apparently benign excavation through a stiff, low permeability till. The case 450 study illustrates the usefulness of continuous monitoring of pore pressures during and post451 construction; this data significantly informed the design of the remediation.

452 The road network in Northern Ireland encompasses a substantial number of large cuttings in 453 tills. Further research sites in similar geological settings have since been identified as potential 454 risks for failure by QUB, TNI and Northern Ireland Railways (NIR); they have continued 455 managing infrastructure slopes by funding continued research (Carse, 2014; McLernon, 2014; 456 Harley et al., 2014; Lynch et al., 2013). Assessing the condition of old cuttings is a vital exercise 
457 in maintaining the integrity of transport infrastructure in the UK. Research into predictive 458 modelling of failure modes due to climate change and reduced long-term shear strength is 459 ongoing, as well as modelling of drainage remediation methods so as to aid the road and rail 460 authorities to better manage their geotechnical assets.

\section{$461 \quad 6.0$ Acknowledgements}

462 The authors would like to acknowledge TransportNI, Construction Service DFPNI, Northern 463 Ireland Railways and the University of Saskatchewan. This research is also a part of an EPSRC 464 funded project, iSMART, "Infrastructure Slopes: Sustainable management and resilience 465 assessment" (http://www.ismartproject.org). This is a unique coalition of 6 academic institutions 466 in the UK (Newcastle University, Durham University, Queen's University Belfast, University of 467 Southampton, Loughborough University and British Geological Survey).

468

469

470

471

472

473

474

475

476

477

478

479

480

481 7.0 References 
Anderson, T.B. (2004) Southern Uplands-Down-Longford Terrane. In: Mitchell, W.I. (ed.) The Geology of Northern Ireland - Our Natural Foundation, second edition. Geological Survey of Northern Ireland, Belfast, 41-60.

Carse, L. (2014) The geomechanical response of cut slopes in glacial till to climatically driven pore-pressure cycling and hydrogeology. PhD Thesis, Queen's University Belfast, United Kingdom.

Clarke, G.R.T. (2007) The impact of climate on the hydrogeology and stability of a large excavation in a glacial till. PhD Thesis, Queen's University Belfast, United Kingdom.

Clarke, G.R.T. (2006) The implications of predicted climate changes on the stability of highway geotechnical infrastructure: A case study of field monitoring of pore water pressure response. IEEE EIC Climate Change Technology Conference, Ottawa, Canada.

Construction Service (2000) SI 99049 A1 Dualling Phase 1 Loughbrickland to Newry, Co. Down. Geotechnical Report SI 99049. Construction Service New Works Division, Geotechnical Section, Roads Service NI (DRD).

Dardis, G.F. and McCabe, A.M. (1984) Characteristics and origins of lee-side stratified sequences in Late-Pleistocene drumlins, Northern Ireland. Earth Surface Processes and Landforms, 9, 409-424.

Doran, I.G. (1992) The subsoils of Northern Ireland. The Structural Engineer, 70(7), 135-138.

Fitzsimons, V.P., Misstear, B.D.R. (2006) Estimating groundwater recharge through tills: a sensitivity analysis of soil moisture budgets and till properties in Ireland. Earth and Environmental Science Hydrogeology Journal Springer Berlin/ Heidelberg, Volume 14, No 4, April, pp 548-561.

Freeze, R.A., Cherry, J.A. (1979) Groundwater. Prentice Hall, Inc.

Geological Survey of Northern Ireland (GSNI) (2004) The geology of Northern Ireland: our natural foundation 2nd edition, Edited by Mitchell, W.I. for Geological Survey of Northern Ireland (GSNI).

Geo-Slope Int. Ltd. (2010) Stress-deformation modelling with SIGMA/W 2007: An engineering methodology. 4th ed. Geo-Slope International Ltd., Calgary, AB, Canada.

Hanrahan, E.T. (1977) Irish Glacial Till: Origin and Characteristics. An Foras Forbartha, RC 164. Dublin. pp.81. 
512 Harley, R., Sivakumar, V., Hughes, D., Karim, M.R.., Barbour, S.L., (2014) Progressive

513 deformation of glacial till due to viscoplastic straining and pore pressure variation.

514 GeoRegina 2014, 67th Canadian Geotechnical Conference Proceedings.

515 Hill, A.R. (1968) An analysis of the distribution and origin of drumlins in North Down and South

516 Antrim, Northern Ireland. PhD Thesis, Queen's University Belfast, United Kingdom.

517 Hughes, D., Sivakumar, V., Glynn, D., Clarke, G., (2007) A Case Study: Delayed Failure of a

518 Deep Cutting in Lodgement Till. Journal of Geotechnical Engineering, ICE, Volume: 160,

519 Issue: 4, Page(s): 193-202 Print ISSN: 1353-2618.

520 Kulpa, K. (2013) Hydrogeological modelling of Northern Ireland drumlins in three dimensions.

521 MSc Thesis, University of Saskatchewan, Canada.

522 Long, M., Menkiti, C.O. (2007) Geotechnical Properties of Dublin Boulder Clay. Geotechnique $523 \quad 57(7)$, pp. 595-611.

524 Lynch, K., Hughes, D., McKinley, J., Bell, A., Harley, R. (2013). Using geotechnical and LIDAR 525 spatial monitoring to determine key environmental slope instability thresholds of a Jurassic

526 coastal landslide: Straidkilly Point, Northern Ireland, UK. GeoMontreal 2013, 66th Canadian

527 Geotechnical Conference Proceedings.

528

McCabe, A.M., Knight, J. and McCarron, S.G. (1999) Ice-flow stages and glacial bedforms in

529

530 north central Ireland: a record of rapid environmental change during the last glacial termination. Journal of the Geological Society. London, 156, 63-72.

McGown, A., Radwan, A. (1974) Cutting slopes in fissured Scottish boulder clay. Proceedings of the $2^{\text {nd }}$ International Congress of the International Association of Engineering Geology. Sao Paulo, Brazil.

McGown, A., Radwan, A. (1975) Presence and influences of fissures in the boulder clays of west-central Scotland. Canadian Geographic Journal 12:1:75.

McGown, A., Sali, A.S., Radwan, A. (1974) Fissure patterns in till at Hurlford, Ayrshire. Quarterly Journal of Engineering Geology 7:1.

McLernon, M. (2014) The influence of climate variability on pore water pressure dynamics and slope stability within glacial till drumlins in Northern Ireland. PhD Thesis, Queen's University Belfast, United Kingdom. Industry Research and Information Association (CIRIA). 
543 van der Kamp, G., Hayashi, M. (2009). Groundwater-wetland ecosystem interaction in the 544 semiarid glaciated plains of North America. Hydrogeology J. 17:203-214.

545

546

547

548

549

550

551

552

553

554

555

556

557

558

559

560

561

562

563

564 Figure captions 
565 Figure 1. Location map (grid in ETRS_1989_UTM_Zone_29N): (a) A1 Carriageway: Belfast to

566 Dublin Euroroute 1 (b) Contour map of drumlin landscape surrounding 'The Three Sisters'

567 drumlin and proposed horizontal alignment of new dual carriageway.

568 Figure 2. Location of the Loughbrickland research site and geology bedrock (The Geological

569 Survey of Northern Ireland, 2004).

570 Figure 3. Locations of boreholes within road cutting (a) Plan of excavation showing borehole

571 locations, bedrock contact zone rock truthing boreholes (RT1-20), and location of Section A-A

572 (b) Vertically expanded cross-section along toe of the slope, including material logs, showing

573 location of flowing artesian conditions (c) Section A-A showing geological profile and borehole

574 locations.

575 Figure 4. Photograph taken during excavation of the Loughbrickland cutting, showing inclusion

576 of high plasticity clay (Clarke, 2007).

577 Figure 5. Permeability of the Loughbrickland site: A and B horizon, upper and lower till and

578 weathered rock zone.

579 Figure 6. Development of flowing artesian condition in the bedrock contact zone at the base of

580 the excavation, showing bedrock water pressures exceeding the overburden total stress.

581 Figure 7. Photographs showing (a) the toe failure as a result of the developed flowing artesian

582 conditions in the bedrock contact zone - September 2004, and (b) the water flow beside BH3

583 caused by artesian conditions in the bedrock contact zone (location at RT10; Figure 3a).

584 Figure 8. Photograph of the repair of cut surface failures as a result of the developed artesian

585 conditions - September 2004.

586 Figure 9. Overview of the observation sites, including TNI BH7, and the location of Section B-B,

587 the 2D groundwater model cross-section at the road cutting, Loughbrickland, Co. Down (Clarke, 588 2007).

589 Figure 10. Pore water pressure and head distribution: (a) pore water pressure and (b) relative 590 head levels versus depth from ground surface (11th April 2005).

591 Figure 11. (a) SEEP/W model showing boundary conditions for initial steady state analysis (b)

592 Total head (mAOD) diagram of initial steady state seepage analysis pre-excavation through

593 section B-B (using SEEP/W).

594 Figure 12. Initial steady state model verification: comparison of field and simulated head data

595 (Borehole 1, 2 \& 3). 
596 Figure 13. (a) Post-excavation stratigraphy (b) Seepage regime showing head contours

597 (mAOD) (c) Artesian seepage conditions at toe showing total head contours (mAOD).

598 Figure 14. Post-excavation factor of safety of major slope failure (using SLOPE/W).

599 Figure 15. Post-remediation conditions, contrasting k with under drainage (a) Stratigraphy and

600 boundary conditions (b) Seepage analysis showing head contours (mAOD) (c) Slope stability 601 analysis.

602

603 Table captions

604 Table 1. Summary of soil classifications.

605 Table 2. Summary of soil strength parameters as measured in the laboratory (Clarke, 2007;

606 McLernon, 2014; Carse, 2014). 